legislatures is predominantly lawyers. This has led, in the case of New York State, to the legislature's passing an amendment to the nofault automobile accident insurance law whereby any doctor treating an automobile accident case must accept the same fee schedule as allowed by workmen's compensation (about half the regular private fee).

A number of New York State orthopaedic surgeons founded a society called the Surgical Specialties Association of New York State to fight this unacceptably low fee schedule. They applied for a legal injunction against the application of the new fee schedule, but this was denied by the courts. In order to bring pressure on the New York State legislature, they then organised a strike against caring for patients under the workmen's compensation laws, except in emergency situations. As the Surgical Specialties Association is not a trades union, the attorney general of New York State has instituted a prosecution against eight orthopaedic members, charging them with conspiracy to have physicians withhold services from patients. This has been felt by many doctors to be a purely political move by the politicians in power gradually to wear down the medical profession.

M G JACOBY

Patchogue,

New York 11772, USA

\section{Money and medicine}

SIR,-In his very amusing excursion through the morals of the just price (21 July, p 220), Professor Rudolf Klein omits an element which would certainly not have escaped any of the earlier commissions whose work on medical remuneration he quotes. For simplicity, this may be referred to as the family investment factor.

While student grants and, more particularly, the appropriate means tests remain at their present level, it would cost two consultants some $£ 7000$, paid out of taxed income, to start an offspring on the same course. This is very much more than if sonny had decided to be a coal miner, or daughter a university teacher. The consultants themselves, if they qualified before the effect of the 1944 Education Act made itself felt, represent an even greater investment by the same family; it is likely that her dowry, rather than the downpayment for a hourse, was some five-sixths of a medical education, a second-hand fur coat, and some medical textbooks which were already becoming obsolete.

Professor Klein is right to say that the schoolmen would have felt at home in the argument. They were notoriously reluctant to admit that a profit on an investment was justified, but I fancy that they would have been acutely sensitive to those factors which resulted in the reduction of the wealth or cirumstances of a family.

KENNETH UlyatT

London SE27 0SR

\section{Remuneration of armed Forces medical services}

SIR,-Figures that I quoted on recruiting to the armed Forces medical services in my report to the Annual Representative Meeting in Liverpool have been challenged by the Ministry of Defence. It maintains that these differ from those quoted by the Armed Forces Pay Review Body in its supplement to the Eighth Report on Medical and Dental Services of the Armed Forces. May I therefore explain the circumstances?

The Review Body Report was published on the last day of the Annual Representative Meeting and I therefore had no opportunity of knowing what figures were to be published; the figures that I used came from earlier estimates, which had been supplied to us officially and which applied to slightly different periods. I must also point out that the Review Body figures included preregistration medical officers, whereas mine referred only to fully qualified practitioners. I regret if this has caused any confusion. However, the differences to which I have referred do not alter the main burden of the argument to be derived from a study of either of these sets of figures. Up to the present time the recruiting figures to the armed Forces medical services and the number of voluntary resignations have given cause not merely for disquiet but also for alarm.

The fully up-to-date remuneration for doctors and dentists in the armed. Forces vigorously pressed for by the British Medical Association and my committee, and now awarded, will we hope do something to alleviate this crisis. This, however, is only start, for we still feel that there has been mis understanding in the way that the present analogue with general practitioners is applied. We shall be studying the whole question of the basis of the pay of doctors and dentists in the armed Forces in our discussions with the Review Body during the course of this year.

J C WatTS London WC1H 9JP Chairman, Armed Forces Committe

\section{VAT on emergency equipment}

SIR,-It seems to me quite irrational that value-added tax should be charged on items of medical equipment which are needed to deal with acute emergencies. I am thinking in particular of defibrillators and monitors. It is essential that departments such as mine should have efficient equipment, and an additional $15 \%$ on top of an already expensive machine makes it increasingly unlikely that this will be obtained.

\section{CyNTHIA IlLingwORTH}

Accident and Emergency Department,

Children's Hospital,
Sheffield S10 2TH

\section{Hospital practitioner grade}

SIR,-At the ARM in Liverpool I asked for the following motion, which my division had introduced, to be withdrawn: "That until recalcitrant hospital consultants expedite the appointment of those suitably 'qualified' persons to the hospital practitioner grade, general practitioners should limit referral to the consultants of private patients." Nevertheless, many general practitioners believe that such action would be warranted.

As well as serving on the Surrey LMC and the Surrey AHA I am a member of the hospital practitioner grade vetting and appointing panel. No general practitioner is ever accepted for the grade until he has been vetted fully by the examining panel and there is full agreement about his suitability. A representa- tive of one of the royal colleges is always present. Why is it that there are such inordinate delays before appointments are made or even substantiated after a candidate has been approved by the panel? My inquiries have shown that it is usually because some consultants-many of them HCSA membersare blocking the way, and I believe this happens because they are jealous of general practitioners' pay yet do not understand how it operates.

Surrey and Berkshire have several such "recalcitrants." When I tackle them the answer has always been, "General practitioners are paid too much as hospital practitioners." General practitioners do not go around asking for consultants' salaries to be reduced; in fact, if they are also competent private practitioners we augment their incomes by sending them private patients. Yet these same consultants are saying that hospital practitioners cannot be appointed because the general practitioners will get as much as a consultant. Why not?

In using such a dog in the manger argument they forget two facts: firstly, a $40 \%$ or more expense factor has to be built into all general practitioners' remuneration from all sources to cover expenses which whole-time consultants never have to bear; secondly, the Review Body judges what consultants should be paid, and for many this can include substantial merit awards. Indeed, the NHS gives a living to many consultants - and perhaps quite a few general practitioners-who in my view could never earn one in private practice.

The hospital practitioner grade should be implemented forthwith. Mr David Bolt has asked general practitioners for their help. We give our support willingly. Now it is time for all consultants to support general practitioners.

Egham, Surrey TW20 0BS

E B ALLEN

\section{Training posts and disillusioned} registrars

SIR,-I read with some concern the letter of Dr Colin Taylor (30 June, p 1798), in which he lays the blame for his predicament and that of other disillusioned registrars on the regional postgraduate advice network. From my experience as a regional postgraduate dean I would like to suggest that in many instances junior doctors must accept some responsibility for their own career frustrations-for example, in selecting oversubscribed specialties unless they are of outstanding calibre. At the same time I would like to say that in discussing career prospects with junior doctors I am continually surprised that it very often appears that career advice from their consultants has been neither sought nor given and also that many doctors do not appreciate the scope and extent of the postgraduate network available to them.

In order to ensure that junior doctors take advantage of the postgraduate facilities available, the regional postgraduate committee of the South-west Thames Region has recommended that it should be written into job descriptions that junior doctors si:ould discuss with their consultant their career aims and aspirations and their proposed training, study leave, etc, when they take up a new post, and should acquaint themselves with the clinical tutor and the postgraduate facilities available. The regional adviser in psychiatry has also recommended writing into the 